\title{
Sexual Function in Obstructive Sleep Apnea Syndrome
}

\section{Obstrïktif Uyku Apne Sendromunda Seksïel Fonksiyon}

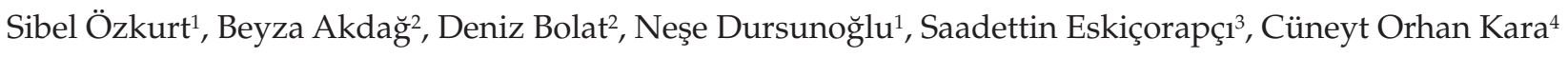 \\ ${ }^{1}$ Pamukkale University Faculty of Medicine, Department of Chest Diseases, Denizli, Turkey \\ 2 Pamukkale University Faculty of Medicine, Department of Biostatistics, Denizli, Turkey \\ ${ }^{3}$ Pamukkale University Faculty of Medicine, Department of Urology, Denizli, Turkey \\ ${ }^{4}$ Pamukkale University Faculty of Medicine, Department of Ear-nose-throat, Denizli, Turkey
}

\section{ABSTRACT}

Aim: Obstructive sleep apnea syndrome (OSAS) is a common medical problem. Among its sequelae, erectile dysfunction (ED) has been reported. The aim of this study aim was to clarify the association between OSAS and ED.

Materials and Methods: The study population consisted of 34 OSAS patients and 13 control patients with simple snoring. Demographics, body mass index (BMI), polysomnography parameters, Epworth Sleepiness Scale (ESS) score, and sexual function situation were noted. All patients underwent urologic examination. The International Index of Erectile Function -5 (IIEF5) was performed to males, and Female Sexual Function Index (FSFI) was performed to females in order to evaluated sexual functions. Patients were grouped as the control group whose apnea- hypopnea index was below 5, and as the study group with respiratory disturbance index $\mathrm{RDI} \geq 5$. The data were statistically analyzed by using Kruskal Wallis Variance Analysis, Mann Whitney U Test with Bonferroni Correction, Independent Samples t Test and Mann Whitney U Test.

Results: ED was found in 24 (70.6\%) of 34 patients on the basis of their symptoms. Most of the patients with ED (40\%) had severe OSAS. There was a statistically significant relation between Body Mass Index (BMI) and ED ( $\mathrm{p}=0.007)$. We found ED in 24 patients according to the IIEF-5 score. There was a statistically significant difference in the minimum $\mathrm{O} 2$ saturation f.indings between the OSAS patients with and without ED ( $\mathrm{p}=0.044)$. Respiratory Disturbance Index (RDI) and ESS were higher in the patients with severe ED in comparison to the patients without ED, but the difference wasn't statistically significant ( $p>0.05)$.

Conclusion: Sexual functions have been found to be affected in patients with OSAS. Additional studies are needed to ascertain the mechanism of ED in OSAS and the treatment of ED in this group of patients.

Keywords: Obstructive sleep apnea syndrome, erectile dysfunction, sexual function

\section{ÖZET}

Amaç: Obstrüktif uyku apne sendromu (OUAS) sık görülen bir durumdur. Sekelleri arasında sertleşme bozukluğu (SB) bulunur. Çalışmamızın amacı OUAS ile SB arasındaki ilişkiyi ortaya koymaktır.

Gereç ve Yöntem: Çalışma popülasyonu 34 OUAS hastasından oluştu. Kontrol grubuna (basit horlama) 13 hasta alındı. Demografik özellikler, beden kitle indeksi (BKI), polisomnografik parametreler, Epworth Uykululuk Skalası (EUS) değeri ve seksüel fonksiyon durumu kaydedildi. Tüm hastaların ürolojik muayeneleri yapıldı. Seksüel fonksiyonlarını değerlendirmek için erkeklere "The International Index of Erectile Function-5 (IIEF-5)", kadinlara "Female Sexual Function Index (FSFI)" uyguland. AHI $<5$ olanlar kontrol grubu, AHİ $\geq 5$ olanlar çalışma grubu olarak kabul edildi. Veriyi analiz etmek için kullanılan istatistiksel yöntemler Kruskal Wallis Varyans Analizi, Bonferroni Düzeltmeli Mann Whitney U Testi, İki Ortalalama Arasındaki Farkın Önemlilik Testi ve Mann Whitney U Testidir.

Bulgular: Semptomlarına göre 34 hastanın 24'ünde (\%70,6) SB saptand. SB'li hastaların çoğu ciddi OUAS'li idi. SB ile Beden Kitle İndeksi (BKI) arasında istatistiksel olarak anlamlı bir ilişki vardı ( $\mathrm{p}=0,007$ ). IIEF-5'e göre de 24 hastada SB bulundu. SB'si olan ve olmayan OSAS'lilerde minimum O2 satürasyonu açısından istatistiksel olarak önemli bir fark vard $1(\mathrm{p}=0,044)$. Respiratory disturbance index(RDI) ve ESS, ciddi SB'li hastalarda SB'si olmayan hastalarla karşılaştırıldığında daha yüksekti ama aradaki fark anlamlı değildi $(\mathrm{p}>0,05)$.

Sonuç: OUAS'lı hastalarda seksüel fonksiyonlar etkilenmektedir. SB'si olan OUAS'li hastalarda SB'nin mekanizması ve SB'nin tedavisi için ek çalışmalara ihtiyaç vardır.

Anahtar kelimeler: Obstrüktif uyku apne sendromu, sertleşme bozukluğu, seksüel fonksiyon

Alındığı tarih: 28 Aralık 2011; Revizyon sonrası alınma: 10 Nisan 2012; Kabul tarihi: 7 Temmuz 2012

Yazışma adresi (Address for correspondence): Sibel Özkurt, Pamukkale Üniversitesi Tıp Fakültesi Göğüs Hastalıkları AD, Denizli ; E-posta: ozkurtsibel@hotmail.com (C) 2012 Türkiye Solunum Araştırmaları Derneği (TÜSAD)

Solunum 2012;14(2):93-98 doi: 10.5505/solunum.2012.53386

Solunum Dergisi'ne www.solunum.org.tr adresinden ulaşabilirsiniz. 


\section{INTRODUCTION AND AIM}

Obstructive sleep apnea syndrome (OSAS) is characterized by repetitive upper airway occlusion (complete or partial), leading to a reduction in breathing rate or cessation of breathing with consequent blood oxygen desaturation and sleep fragmentation. ${ }^{1,2}$ It is a common medical problem affecting up to $5 \%$ of men and $4 \%$ women in their middle ages. ${ }^{1,3}$ Severity is assessed by two parameters: the respiratory disturbance index (RDI); that is the number of sleep apnea episodes during an hour; and the minimal oxygen saturation, measured by pulse oximetry, during the apnea episodes. ${ }^{1}$

OSAS is associated with clinical complications such as: daytime somnolence, hypertension, ischemic heart diseases, and increased risk of stroke. Among its sequelae, erectile dysfunction (ED) has been reported. ${ }^{2}$ Several studies have found a high prevalence of Erectile Dysfunction (ED) in patients with OSAS. ${ }^{4,5} \mathrm{ED}$ has been mentioned as a symptom of OSAS as early as 1977 and has been reported since then by others. ${ }^{4,6-8}$ But it has not been systematically explored, even when quality of life is considered. ED is defined by the National Institutes of Health (NIH) as the inability to achieve and maintain an erection sufficent to permit satisfactory sexual intercourse. ${ }^{9,10}$ Underlying pathological mechanisms include recurrent intermittent hypoxemia and increased sympathetic activity, primarily at the termination of the apneic events. ${ }^{11}$ An erection is achieved by an integration of psychological, neural, hormonal, and vascular systems. A problem in any of these may cause ED. ${ }^{12}$ The projected prevalence for 2025 is 322 million men with the largest increase expected in the developing countries. ${ }^{9}$

Little advance has occurred in the understanding of ED and its association with OSAS. There are many physiological challenges associated with OSAS to support a theoretical relationship between OSAS and ED, such as increased sympathetic tone, endothelial dysfunction, intermittent hypoxia, etc. ${ }^{3}$

In a study, it has been shown that ED is associated with OSAS in a dose-related fashion. This association is very strong in patients with severe OSAS and weaker in patients with mild or moderate OSAS. ${ }^{12}$ These findings are supported by several other studies reporting a high prevalence (30-68\%) of ED in patients with OSAS. ${ }^{4,5}$

The objective of our study was to clarify the association between OSAS and ED through a prospective study.

\section{MATERIAL AND METHODS}

Before initiating the study, we obtained the approval of local ethics committee of our university. The study was in compliance with the Helsinki declaration 2008.

The study population consisted of patients referred to the sleep laboratory of our university hospital between 2008 and 2009 for polysomnographic study for symptoms suggestive of sleep-related abnormality. Patients were included in the study after a written informed consent was obtained. Demographic information was recorded and the body mass index (BMI) was calculated on the computer as weight divided by height squared $\left(\mathrm{kg} / \mathrm{m}^{2}\right)$. Patients with BMI of 18.5-24.9 were grouped as normal, 25-29.9 as overweight, and those with $\geq 30$ as obese. Medical history and co-morbid diseases such as hypertension, coronary diseases, diabetes mellitus, depression, sexual dysfunctions and the polysomnography parameters were noted for each patient. All patients underwent clinical evaluation including physical and urologic examination. Erectile dysfunction was questioned in patients. If there was inability to achieve and maintain an erection suffient to permit satisfactory sexual intercourse it was named as ED. The International Index of Erectile Function -5 (IIEF-5), International Prostate Symptom Scala (IPSS) were determined in the males, and Female Sexual Function Index (FSFI) was determined in the females in order evaluated sexual function in both sexes. Male patients were distributed into three groups according to IIEF-5 scores. ${ }^{13,14}$

Female patients were also grouped according to the severity of FSFI. FSFI score below 23 was taken as severe, a score of 23-29 as moderate, and a score of $\geq 30$ was taken as normal.

Each patient was asked to fill out the Epworth Sleep Scale (ESS); which is a simple and reliable self-administrated test measuring the level of daytime sleepiness in patients with OSAS. ${ }^{15}$ All patients underwent full-night polysomnography (Compumedics-P series, Australia). The recordings consisted of electroencephalogram (EEG) (C3/A2, C4/A1,O1/A2, $\mathrm{O} 2 / \mathrm{A} 1$ ), chin and leg electromyogram (EMG), electrooculogram (EOG), electrocardigram (ECG), body position and respiration. Respiration was monitored using nasal and oral thermistors, by conducting uncalibrated inductive respiratory plethysmography, pulse oximetry, and by placement of a neck microphone. The patients slept between $11 \mathrm{pm}$ and $7 \mathrm{am}$. Data were scored using adult AASM criteria. Hypopnea was defined as $>30 \%$ decrement in flow and oxygen desaturation of $4 \%$ or more. ${ }^{16}$ Apnea was defined as the complete cessation of airflow for at least 10 seconds. The respiratory disturbance index (RDI) was calculated by dividing the total number apnea events and hypopnea events by the total sleep time. According to the level of the respiratory disturbance index (RDI) determined by the polysomnography, the patients were grouped as having mild $(5<\mathrm{RDI} \leq 15)$, moderate $(15<\mathrm{RDI} \leq 30)$, or severe $(\mathrm{RDI}>30)$ OSAS.

Patients with apnea- hypopnea index below 5 were grouped as the controls and those with RDI $\geq 5$ constituted the study group.

The SPSS 10.0 package program was used for analysis. The data were statistically analyzed by using Kruskal Wallis 
Variance Analysis, Mann Whitney U Test with Bonferroni Correction, and Independent Samples t Test, Mann Whitney $\mathrm{U}$ Test. The descriptive statistics are given as frequency, percentage and mean \pm standard deviation. The statistical significance was set at $\mathrm{P}<0.05$.

\section{RESULTS}

In our study 34 (72.4\%) of 47 patients were male, $13(27.6 \%)$ of 47 patients were female. The mean age of all patients was $53.69 \pm 7.29$, and the mean BMI of all was $31.28 \pm 4.95$. Of the 34 patients with OSAS, $11(32.4 \%)$ had mild, 8 (\%23.5) had moderate, 15 (44.1\%) had severe disease, while 13 patients with simple snoring were taken as the control group. Identification of OSAS severity according to gender and mean ages is shown in Table I.

Severe OSAS was higher in the male population. Mean age of the OSAS patients was $54.72 \pm 7.17$, while the mean age of control group was $47.56 \pm 4.28$.

Erectile dysfunction was found in $24(70.6 \%)$ of 34 OSAS patients on the basis of their symptoms. Among the patients with ED, percentages of patients with mild, moderate, and severe OSAS were $29.4 \%, 23.5 \%, 47.1 \%$ respectively. No statistically significant relation was found between ED and the severity of OSAS.

BMI was $33.01 \pm 4.71$ in the patients with $\mathrm{ED}$, while BMI was $28.24 \pm 3.65$ in the patients without ED. Of the 24 patients with ED 17 (70.8\%) were overweight; 7 (29.2\%) were obese.
There was a statistically significant relation between BMI and $\mathrm{ED}(\mathrm{p}=0.007)$.

ED was observed in $12(66.7 \%)$ of 18 OSAS patients with co-morbidity, while $6(33.3 \%)$ of these patients were without ED. However, no statistically significant, percentage difference was found between two groups ( $p>0.05$ ).

Minimum oxygen saturation (O2 sat.), median $\mathrm{O}_{2}$ sat, RDI, ESS in patients with ED are shown in Table II. There was no statistically significant relation between ED and the minimum and median $\mathrm{O}_{2}$ sat, RDI and ESS data. Of the 24 patients with ED, 8 (33\%) were below 55 years old, and 16 $(66 \%)$ were $\geq 55$ years old. No significant relation was found between ED and age.

We found ED in 24 patients according to the IIEF- 5 score. IIEF-5 results in OSAS patients are shown in Table III. IIEF5 results according to OSAS severity are shown in Table IV. We did not perform statistical matching because of the small number of patients. Minimum $\mathrm{O}_{2}$ sat. median $\mathrm{O}_{2}$ sat., RDI, ESS values according to IIEF-5 results are shown in Table V.

There was a statistically significant difference between the minimum $\mathrm{O}_{2}$ saturation of male OSAS male patients with and without ED according to the IIEF-5 scoring ( $\mathrm{p}=0.044)$. While the mean $\mathrm{O}_{2}$ saturation was lower, RDI and ESS were higher in the patients with severe ED in comparison with patients without ED but the difference wasn't statistically significant $(\mathrm{p}>0.05)$.

Morning erection was seen in $11(32.5 \%)$ of 34 patients. OSAS severity in 11 patients with morning erection was shown in Table VI. There was no statistically significant

Table I. Distribution of risk factors among patients with VTE risk

\begin{tabular}{|c|c|c|c|c|c|c|c|c|}
\hline \multirow{2}{*}{$\begin{array}{l}\text { Sex and } \\
\text { Age }\end{array}$} & \multicolumn{2}{|c|}{ Mild OSAS } & \multicolumn{2}{|c|}{ Moderate OSAS } & \multicolumn{2}{|c|}{ Severe OSAS } & \multicolumn{2}{|c|}{ Control } \\
\hline & n & $\%$ & $\mathbf{n}$ & $\%$ & $\mathbf{n}$ & $\%$ & $\mathrm{n}$ & $\%$ \\
\hline Male & 6 & 17.6 & 5 & 14.7 & 14 & 41.2 & 9 & 26.5 \\
\hline Age & \multicolumn{2}{|c|}{$58.33 \pm 7.45$} & \multicolumn{2}{|c|}{$51.40 \pm 6.31$} & \multicolumn{2}{|c|}{$54.36 \pm 7.14$} & \multicolumn{2}{|c|}{$53.78 \pm 9.83$} \\
\hline Female & 5 & 38.4 & 3 & 23.1 & 1 & 7.7 & 4 & 30.8 \\
\hline Age & \multicolumn{2}{|c|}{$47.00 \pm 3.46$} & \multicolumn{2}{|c|}{$49.33 \pm 6.35$} & \multicolumn{2}{|c|}{$45.00 \pm 0.00$} & \multicolumn{2}{|c|}{$48.00 \pm 0.82$} \\
\hline
\end{tabular}

Table II. Minimum and median oxygen saturation., RDI, ESS in patients with ED

\begin{tabular}{|l|l|l|l|l|l|}
\hline \multicolumn{1}{|c|}{ ED } & Min.02 sat. & Median.02 sat & RDI & ESS \\
\hline $\begin{array}{l}\text { Yes } \\
n=24,\end{array}$ & $70.6 \%$ & $81.60 \pm 8.70$ & $92.40 \pm 3.57$ & $25.76 \pm 20.45$ & $8.20 \pm 5.88$ \\
\hline $\begin{array}{l}\text { No } \\
n=10,\end{array}$ & $29.4 \%$ & $84.00 \pm 8.00$ & $93.21 \pm 2.33$ & $24.78 \pm 25.13$ & $8.00 \pm 6.83$ \\
\hline$p>0.05$ & & & &
\end{tabular}


Table III. IIEF-5 results in OSAS patients

\begin{tabular}{|l|c|c|}
\hline \multirow{2}{*}{ IIEF-5 results } & \multicolumn{2}{|c|}{ OSAS patients } \\
\hline Severe & $\mathbf{n}$ & $\%$ \\
\hline Mild & 16 & 47.1 \\
\hline Normal & 8 & 23.5 \\
\hline
\end{tabular}

Table IV. IIEF-5 results according to OSAS severity

\begin{tabular}{|c|c|c|c|}
\hline IIEF-5 results & OSAS severity & $\mathbf{n}$ & $\%$ \\
\hline \multirow{2}{*}{ Severe } & Mild & 5 & 31.3 \\
\hline \multirow{2}{*}{ Mild } & Moderate & 4 & 25.0 \\
\hline & Severe & 7 & 43.7 \\
\hline & Mild & 4 & 50.0 \\
\hline & Moderate & 1 & 12.5 \\
\hline
\end{tabular}

relation between OSAS severity and morning erection $(\mathrm{p}>0.05)$. All of the 11 patients who had morning erection were below 55 years of age, and no statistically significant relation was found between morning erection capability and age $(\mathrm{p}>0.05)$.

Of the 34 patients, $15(44.1 \%)$ had premature ejaculation. OSAS classification of 15 patients with premature ejaculation was shown in Table VII. No statistically significant relation was found between premature ejaculation and OSAS classification $(\mathrm{p}>0.05)$. Of these 15 patients, $8(53.3 \%)$ were below 55 years old; 7 ( $46.7 \%$ ) were $>55$ years old. There was no statistically significant relation between age and premature ejaculation ( $\mathrm{p}>0.05)$.

IPSS was assessed in 33 patients and was found to be mild in $13(39.4 \%)$, moderate in $17(51.5 \%)$, and severe in $3(9.1 \%)$. None of the males were using sildenafil.
Of the 13 female patients; $9(69.3 \%)$ had OSAS with 5 $(55.6 \%)$ having mild, 3 (33.3\%); moderate, and 1 (11.1\%); severe disease. Three (23.1\%) female patients had bad results in sexual functions when analysed with FSFI scala.

All patients $37(78.8 \%)$ had morning fatigue.

\section{DISCUSSION}

In 1981, a review of 100 OSAS patients followed and treated with tracheostomy for their syndrome indicated that 48 had erection problems. Sexual dysfunction was reported as commonly associated with OSAS late in the 1970s and the early 1980 s. ${ }^{15}$

Although the etiologic association between OSAS and ED is controversial, sexual problems are common among men with sleep apnea-hypopnea. An incidence of $48 \%$ of sexual problems has been reported among men aged 25-65 y with sleep apnea. ${ }^{16}$ On the other hand, a high rate of sleep disorders ranging from 44 to $61 \%$ was detected during nocturnal penile tumescence studies in men with $\operatorname{ED}(4,8)$. Twenty-five years ago, Guilleminault et al. observed that $48 \%$ of men with OSAS had sexual dysfunction. ${ }^{15,16}$ More recently, ED has been reported to occur in 30-50\% of men with OSA. ${ }^{12,13,17}$ Gonçalves et al. found that $28.6 \%$ of their subjects had clinical sexual dysfunction present for over six months. ${ }^{13}$

In our study, ED was present in $70.6 \%$ of the male OSAS patients. RDI of ED patients were higher than that seen in patients without ED, although there was not a statistically significant difference. Also RDI values were higher in the patients having mild and severe IIEF-5 results when compared with the group having no sexual dysfunction.

Older age has been shown in numerous studies to correlate with the severity of both OSAS and ED. ${ }^{18,19}$ In our study we couldn't find any relation between age and ED. The underlying mechanism behind ED in OSAS patients is unclear. The etiology could be multi-factorial. ${ }^{13}$ OSAS may not be the primary etiology of ED. OSAS by leading to an autonomic dysfunction; may be an independent cause of ED. ${ }^{13}$

Table V. Minimum, median 02 sat., RDI, ESS values according to IIEF-5 results

\begin{tabular}{|c|c|c|c|c|}
\hline IIEF-5 results & Min 02 sat $^{*}$ & Median.02 sat* * & RDI** & ESS** \\
\hline Mild $(n=8)$ & $89.40 \pm 9.68$ & $92.45 \pm 4.19$ & $30.28 \pm 2184$ & $9.67 \pm 6.16$ \\
\hline Normal $(n=10)$ & $87.00 \pm 4.29$ & $93.80 \pm 1.87$ & $13.69 \pm 17.56$ & $4.70 \pm 5.06$ \\
\hline
\end{tabular}


Table VI. OSAS severity in 11 patients with morning erection

\begin{tabular}{|c|c|c|}
\hline OSAS severity & $\mathbf{n}$ & $\%$ \\
\hline Mild & 3 & 27.3 \\
\hline Moderate & 1 & 9.1 \\
\hline Severe & 7 & 63.6 \\
\hline
\end{tabular}

Table VII. OSAS classification of 15 patients with premature ejaculation

\begin{tabular}{|c|c|c|}
\hline OSAS severity & $\mathbf{n}$ & $\%$ \\
\hline Mild & 3 & 20.0 \\
\hline Moderate & 5 & 33.3 \\
\hline Severe & 7 & 46.7 \\
\hline
\end{tabular}

Fanfulla et al. found that hypoxemia during sleep seems to be an important element in the presence of ED and suggested that the mechanism for this association may be mediated by hypoxia-induced occult nerve dysfunction. ${ }^{7}$ Gonçalves et al. found that OSA was also associated with significantly lower $\mathrm{SaO}_{2}$ compared to non-affected men matched for age and BMI at baseline. A significantly higher incidence of $\mathrm{ED}$ was observed in the subjects with $\mathrm{SaO} 2$ drop $<89 \% .{ }^{13}$ In our study, there was a statistically significant difference in minimum $\mathrm{O} 2$ saturation between the OSAS male patients with and without ED, which suggests that hypoxia might cause erectile dysfunction.

Guilleminault suggested that sleep fragmentation might be a predisposition factor for ED. ${ }^{20}$ In our study, ESS was higher in the patients with ED. ESS was also higher than normal in the patients having severe sexual disfunction according to IIEF-5.

ED represents a model of endothelial dysfunction, and is often related with comorbidites such as diabetes mellitus, atherosclerosis, hypertension and coronary artery disease. ${ }^{21}$ Hypoxic episodes are common in sleep apnea and in coordination with the arousals-related, end-apneic hyperadrenergic reactions may be responsible for OSASassociated complications, including ED. ${ }^{7}$ OSAS may be responsible for mood changes, metabolic changes, autonomic nervous system dysfunction and even weight gain. Some of these changes may not only be directly related to apnea and hypopnea but also secondarily related to the OSA-induced sleep restriction and metabolic changes. It is often assumed that ED is related to aging, obesity, medication intake, mood disorder, and other variables. ${ }^{13}$ Margel et al. believe that the end result of ED in OSAS originates from a combination of both organic and psycogenic mechanisms. ${ }^{12}$ Limitations in our study was not only due to the small study group but also to the comorbities of our patients in whom ED was higher. Other limitation of this study was not assessing important confounding variables such as diabetes, hyperlipidemia, or hypertension.

The association of erectile dysfunction with OSAS has been studied, but no study has assessed its impact on female sexual function. ${ }^{12}$ OSAS affects up to $4 \%$ of women between the ages of 30-60 years, with adverse consequences on health-related quality of life. ${ }^{22,23}$ In the literature, several studies have addressed the impact of co-morbid diseases on female sexual function. ${ }^{24,25}$ Sexual dysfunction in women is primarily related to aging and menapouse or estrogen deficiency, and it affects up to $40 \%$ of the women population. ${ }^{24,26}$ Comorbid diseases like hypertension, diabetes mellitus type I and II have been shown to be related with FSD independent of aging. ${ }^{24,27}$ The overall gender ratio of sleep apnea for men:women is $3: 1$, and the prevalence decreases to $0.6 \%$ in the premenopausal women. ${ }^{28}$ Female sexual dysfunction is an age-related problem affecting a significant proportion of the female population..$^{26,29}$ In a recent global epidemiological study, certain sexual functions were determined to be affected in up to $40 \%$ of the female population. ${ }^{30}$ Women patients with OSAS and sexual dysfunction may have even a worse quality of life related to these independent factors. Obstructive sleep apnea syndrome diminishes sexual function in premenopausal women independent of age and co-morbid disease. ${ }^{3}$

In our study, female population was small. Sexual function is effected negatively in $23.1 \%$ of females with OSAS. Mean age of females was younger than that of the male group, but not all of the women were premenapausal.

\section{CONCLUSION}

Sexual functions have been affected in patients with OSAS. We have confirmed a correlation between severe OSAS and ED and a relation between severity of OSAS and the presence of sexual dysfunction. We have shown that there was a significant difference in minimum $\mathrm{O}_{2}$ saturation of OSAS male patients with and without ED. Especially nocturnal intermittent hypoxia might affect sexual function negatively. When evaluating a patient who complains of impotence, OSAS should be considered. It is recommended that patients who have a high RDI should be asked about their sexual function and referred for an urologic consultation when needed. Additional studies are needed to ascertain the mechanism of ED in OSAS and the treatment of ED in this group of patients.

\section{Conflict of Interest}

There is no conflict of interest between the authors. 


\section{REFERENCES}

1. Margel D, Tal R, Livne PM, Pillar G. Predictors of erectile function improvement in obstructive sleep apnea patients with long- term CPAP treatment. International Journal of Impotence Research 2005; 17:186-190.

2. Perimenis P, Karkokulias K, Markou S, Gyftopoulos K, Athanasopoulos A. Erectile dysfunctionin men with obstructive sleep apnea syndrome: a randomized study of the efficacy of sildenafil and continuous positive airway pressure. International Journal of Impotence Research 2004;16:256-260.

3. Köseoğlu N, Köseoğlu H, Itil O, Öztura I, Baklan B, İkiz AO, et al. Sexual function status in women with obstructive sleep apnea syndrome. J Sex Med 2007;4:1352-1357.

4. Pressman MR, Dipillipo MA, Kendrick JI, Conroy K, Fry JM. Problems in the interpretation of nocturnal penile tumescence: disruption of sleep by occult sleep disorders. J Urol 1986:136:595598.

5. Hirshkowitz M, Karacan I, Arcasoy MO, Acik G, Narter EM, Williams RL. Prevalence of sleep apnea in men with erectile dysfunction. Urology 1990;36:232-234.

6. Guilleminault C. Clinical features and evaluations obstructive sleep apnea.In: Kryger Meir H, Roth Thomas, Dement William C, editors. Principles and practice of sleep medicine. 2nd ed. Philadelphia. PA: WB Saunders; 1994.

7. Fanfulla F, Malaguti S, Montagna T, Salvini S, Bruschi C, Crotti P, et al. Erectile dysfunction in men with obstructive sleep apnea: an early sign of nerve involvement. Sleep 2000;23:775-780.

8. Hirshkowitz M, Karacan I, Gurakar A, Williams RI. Hypertension, erectile dysfunction, and occult sleep apnea. Sleep 1989;12:223-232.

9. Ayta IA, McKinlay JB, Krane RJ. The likely worldwide increase in erectile dysfunction between 1995 and 2025 and somepossible policyconsequences. BJU Int 1999;84:50-56.

10. NIH Consensus Development Panel: Impotence. JAMA 1993;270: 83-90.

11. Katragadda S, Xie A, Puleo D, Skatrud JB, Morgan BJ. Neural mechanism of the pressor response to obstructive and nonobstructive apnea. J Appl Physiol 1997;83:2048-2054.

12. Margel D, Cohen M, Livne PM, Pillar G. Severe, but not mild, obstructive sleep apnea syndrome is associated with erectile dysfunction. Urology 2004;3:545-549.

13. Rosen RC, Cappelleri JC, Smith MD, Lipsky J, Pena BM. Development and evaluation of and a bridged, 5 -item version of the International Index of Erectile Function (IIEF-5) as a diagnostic tool for erectile dysfunction. International Journal of Impotance Research 1999;11:319-326.

14. Samatha KH, Hendren SK, Connor BI, Liu M, Asano T, Swallow CJ, et al. Prevalance of male and female sexual dysfunction is high following surgery for rectal cancer. Annals of Surgey 2005;242:212223.

15. Johns MW. A new method for measuring daytime sleepiness scala. Sleep 1991;14:540-545.

16. Clebras A. Polisomnography. In Clinical of sleep disorders. Butterworth-Heinemann, Boston: 1996:91-117.

17. Gonçalves MA, Guilleminault C, Ramos E, Palha A, Paiva T. Erectile dysfunction, obstructive sleep apnea syndrome and nasal CPAP treatment. Sleep Medicine 2005;6:333-339.

18. Iber C, Acoli-Israel, Chesson A, and Quan SF. fort the American
Academy of Sleep Medicine. The AASM Manual for the Scoring of Sleep and Associated Events: Rules, Terminology and Technical Specfications, 1st.: Westchester, Illinois: American Academy of Sleep Medicine, 2007.

19. Guilleminault C, Simmons FB, Motta J, Cummiskey J, Rosekind M, Schroeder JS, et al. Obstructive sleep apnea syndrome and tracheostomy: long-term follow-up experience. Arch Intern Med 1981;141:985-988.

20. Guilleminault C, Eldridge FL, Tilkian A, Simmons FB, Dement WC. Sleep apnea syndrome due to upper airway obstruction.: A review of 25 cases. Arch Intern Med 1977;137:296-300.

21. Grunstein RR, Handelsman DJ, Lawrence SJ, Blackwell C, Caterson ID, Sullivan CE. Neuroendocrine dysfunction in sleep apnea syndrome: reversal by nasal continuous positive airway pressure. J Clin Endocrinol Metab 1989;68:352-358.

22. Schiavi RC, Schreiner-Engel P, Mandeli J, Schanzer H, Cohen E. Healthy aging and male sexual function. Am J Psychiatry 1990;147: 766-71.

23. Karacan I, Williams RL, Thornby JI, Salis PJ. Sleep related penile tumescence as a function of age. Am J Psychiatry 1975;132:932-936.

24. Seftel AD, Strohl KP, Loye TL, Bayard D, Kress J, Netzer NC. Erectile dysfunction and symptoms of sleep disorders. Sleep 2002;25:643-647.

25. Lewis RD, Hatzichriston DG, Laumann E, McKinlay JB. Epidemiology and natural history of erectile dysfunction: risk factors including iatrogenic and ageing. In: Jardin A, Wagner G, Khoury S, Giuliano F, Goldstein I, Padma-Nathan H (eds). Recommendations of the First International Consultation on Erectile Dysfunction, cosponsored by the World Health Organization (WHO). Plymouth: Health Publication Ltd, 2000; p. 21-51.

26. Young T, Palta M, Dempsey J, Skatrud J, Weber S , Badr S. The occurrence of sleep-disorded breathing among middle aged adults. N England J Med 1993;328:1230-1235.

27. Finn L, Young T, Palta M, Fryback DG. Sleep-disordered breathing and self-reported general health status in the Wisconsin Sleep Cohort Study. Sleep 1998;21:701-706.

28. Lewis RW, Fugl-Meyer KS, Bosch R, Fugl-Meyer AR, Laumann EC, Lizza E, et al. Epidemiology / risk factors of sexual dysfunction. J Sex Med 2004;1:35-39.

29. Duncan LE, Lewis C, Jenkins P, Pearson TA. Does hypertension and its pharmacotherapy affect the quality of sexual function in women? Am J Hypertens 200;13:640-647.

30. Spector IP, Carey MP. Incidence and prevalence of the sexual dysfunctions: A critical review of the empirical literature. Arch Sex Behav 1990;19:389-408.

31. Enzlin P, Mathieu C, Van Den Brual A, Vanderschueren D, Demyttenaere K. Prevalence and predictors of sexual dysfunction in patients with type 1 diabetes. Diabetes Care 2003;26:409-414.

32. Bixler EO, Vgontzas AN, Lin HM, Ten Have T, Rein J, Vela-Bueno A, et al. Prevalence of sleep-disordered breathing in women. Effects of Gender. Am J Respir Crit Care 2001;163:608-613.

33. Rosen RC, Taylor JF, Leiblum SR, Bachmann GA. Prevalence of sexual dysfunction in women: Results of a survey study of 329 women in an outpatient gynecological clinic. J Sex Marital Ther 1993;19:171-188.

34. Laumann EO, Nicolosi A, Glasser DB, Paik A, Gingell C, Moreira E, et al. Sexual problems among women and men aged 40-80 y: Prevalence and correlates identified in the Global Study of Sexual Attitudes and Behaviors. Int J Impot Res 2005;17:39-57. 